\title{
Beytepe Asker Hastanesine Bassvuran Hastalarda HBs Ag, Anti-HBs, Anti-HBc Total ve Anti-HCV Seroprevalansı $\mathrm{HBs}$ Ag, Anti-HBs, Anti-HBc Total and Anti-HCV Seroprevalence of the Patients Applied to Beytepe Military Hospital
}

\author{
Mehmet ÇOBAN1, Erdim SERTOĞLU2

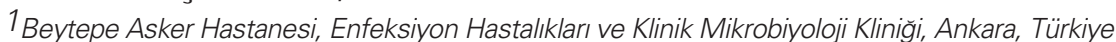 \\ 2 Beytepe Asker Hastanesi, Tıbbi Biyokimya Kliniği, Ankara, Türkiye
}

\section{ÖZET}

Amaç: Hepatit B ve C virüs enfeksiyonları, siroz ve hepatosellüler karsinomanın en önemli nedenlerinden olup günümüzde hem ülkemiz hem de dünya genelinde önemli bir sağlık problemi olmaya devam etmektedirler. Bu çalısma ile 01 Haziran 2011-31 Mayıs 2013 tarihleri arasında Beytepe Asker Hastanesi'ne başvuran hastalarda HBsAg, Anti-HBs, Anti-HBc total ve AntiHCV seropozitifliklerini araştırmayı amaçladık.

Yöntemler: Beytepe Asker Hastanesi'ne çeşitli nedenlerle başvuran ve çalışmada belirtilen serolojik testleri istenen 11758 hastanın, tıbbi kayıtları geriye dönük olarak değerlendirildi. HBsAg, Anti-HBs, Anti-HBc total ve AntiHCV düzeyleri kemilüminesan immünoassay (Architect i1000SR, Abbott, ABD) yöntemiyle ölçüldü. Çalışma, Gülhane Askeri Tıp Akademisi yerel etik kurul komitesinin 03 Temmuz 2013 tarih-1655 sayılı izni ile gerçekleştirildi.

Bulgular: Toplam olarak 11758 hastanın kayıtları geriye dönük olarak değerlendirilmiştir. Değerlendirme sonucunda 11728 hastanın 298 'inde HBsAg pozitifliği (\%2,54), 2378 hastanın 1044'ünde Anti-HBs pozitifliği (\%43,9), 1256 hastanın 291 'inde Anti-HBc total pozitifliği $(\% 23,17)$ ve 7615 hastanın 42' sinde $(\% 0,55)$ Anti-HCV pozitifliği saptandı. Cinsiyetlere göre değerlendirildiğinde erkeklerdeki HBsAg, Anti-HBs, Anti-HBc total ve Anti-HCV pozitifliği sırasıyla $\% 2,62, \% 42,22, \% 24,86$ ve $\% 0,57$ olarak tespit edilmiştir. Kadınlardaysa bu oranlar sırasıyla $\% 1,19, \% 53,74, \% 13,92$ ve $\% 0,32$ olarak bulunmuştur.

Sonuç: Calıșmamızda tespit ettiğimiz HBsAg, Anti-HBs ve Anti-HCV seropozitiflik oranları, ülkemizde yapılan diğer çalışmalar ile uyumlu bulunmuștur. Önümüzdeki yıllarda ülkemizde Anti-HCV seropozitifliğinde değişiklik gözlenmeyebilir. Ancak, 1998 yılından beri yenidoğanların aşılanmaya başlamış olması dolayısıyla HBsAg pozitifliğinde azalma ve AntiHBs pozitifliğinde artıș olması beklenmektedir. Bunun sağlanabilmesi için uygulanan viral hepatit eğitim ve aşı programlarına ara verilmeden devam edilmelidir. (Viral Hepatit Dergisi 2013; 19(3): 152-5)

Anahtar Kelimeler: Hepatit B, hepatit C, seroprevalans

\section{ABSTRACT}

Objective: Hepatitis B virus $(\mathrm{HBV})$ and hepatitis $\mathrm{C}$ virus $(\mathrm{HCV})$ infections are a worldwide health problem which may result in cirrhosis and hepatocellular carcinoma. In this study, we aimed to determine the seroprevalences of hepatitis B surface antigen (HBs Ag), hepatitis B surface antibody (Anti-HBs), hepatitis B core antibody (Anti-HBc Total) and HCV antibody (Anti-HCV) in patients admitted to our hospital between June 01, 2011-May 31, 2013.

Methods: Medical records of 11758 patients, including serological tests mentioned in the study, were evaluated retrospectively. HBs Ag, Anti-HBs, Anti HBc Total and Anti-HCV markers were analyzed by chemiluminescence immunoassay method with Architect i1000SR (Abbott, USA) autoanalyser. The study made with the permission of Gulhane Military Medical Academy local ethics committee.

Results: When the records of 11758 patients evaluated retrospectively, there were seropositivity of HBs Ag in 298 of 11728 patients (2.54\%), positivity of Anti-HBs in 1044 of 2378 patients (43.9\%), positivity of Anti-HBc Total in 291 of 1256 patients (23.17\%) and seropositivity of Anti-HCV in 42 of 7615 patients (0.55\%). According to gender, men's HBs Ag, anti-HBs, anti-HBc total and anti-HCV positivity rates were $2.62 \%, 42.22 \%, 24.86 \%$ and $0.57 \%$, respectively; while women's rates were $1.19 \%, 53.74 \%, 13.92 \%$ and $0.32 \%$, respectively.

Conclusion: HBsAg, anti-HBs and anti-HCV seropositivity rates which we have detected in this study were consistent with other studies conducted in in our country. Over the years there may not seen any changes as Anti-HCV seropositivity. However, because of the immunization of newborns since 1998, decrease in HBsAg positivity and increase in anti-HBs positivity are expected. (Viral Hepatitis Journal 2013; 19(3): 152-5)

Key words: Hepatitis B, hepatitis C, seroprevalance

Yazıșma Adresi/Address for Correspondence: Dr. Mehmet Çoban, Beytepe Asker Hastanesi, Enfeksiyon Hastalıkları ve Klinik Mikrobiyoloji Kliniği, Ankara, Türkiye GSM: +90 5052588991 E-posta: mcobanmd@gmail.com Geliş tarihi/Received: 07.09.2013 Kabul tarihi/Accepted: 09.10.2013 (c) Viral Hepatit Dergisi, Galenos Yayınevi tarafindan basılmıștır. / Viral Hepatitis Journal, published by Galenos Publishing. 


\section{Giriş}

Viral hepatitler tüm dünyada yaygın olarak görülen enfeksiyonlardır. Bunlardan özellikle Hepatit B (HBV) ve hepatit C virüs $(\mathrm{HCV})$ enfeksiyonları, siroz ve hepatoselüler karsinomanın en önemli nedenlerinden olup günümüzde hem ülkemiz hem de dünya için önemli bir sağlık problemi olmaya devam etmektedirler.

HBV başlıca parenteral, vertikal ve cinsel temas yolu ile bulaşmakla birlikte toplu yaşam alanlarında ve aile içinde yakın temasla horizontal bulaş da gözlenmektedir. Dünya üzerinde en az 2 milyar insanın HBV ile enfekte, 378 milyondan fazla kişinin ise kronik taşıyıcı olduğu tahmin edilmektedir (1). HBV yayılmasında bu kronik taşıyıcılık kavramı oldukça önemlidir. HBV enfeksiyonunun dünyadaki dağılımı coğrafi bölgelere göre farklııklar göstermektedir. Ülkemiz HBV enfeksiyonu açısından Dünya Sağlık Örgütü (DSÖ) sınıflamasında Güney ve Doğu Avrupa, Güney ve Orta Amerika, Orta Asya ve Ortadoğu'nun yer aldığı orta endemisite (\%2-8) bölgesinde yer almaktadır. Ülkemizde toplumun genel durumunun belirlenmesi ve transfüzyonla bulaşan enfeksiyonların önüne geçilebilmesi amacıyla kan donörleri üzerinde yapılan çalışmalarda HBsAg pozitifliği oranının \%2,8-10,75 aralığında olduğu tespit edilmiştir (2).

HCV bulaş yolları HBV ile benzerlik göstermekle birlikte başlıca parenteral yolla bulaşmaktadır. Dünyada yaklaşık 170 milyon insanın HCV ile enfekte olduğu tahmin edilmektedir. Avrupa'da prevalans \%0,5-2 arasında değişmekle birlikte, ülkemizdeki AntiHCV pozitifliğinin \%1 civarında olduğu bildirilmektedir (3).

Ülkemizde HBV ve HCV prevalansı ile ilgili olarak çok sayıda araştırma yayınlanmıştır. Çalışmaların çoğu kan donörlerinde yapılmıştır. Biz bu çalışmamızda, hastanemize başvuran çeşitli yaş gruplarındaki hastalarda HBs Ag, Anti-HBs, Anti-HBc total ve AntiHCV seroprevalansını belirlemeyi amaçladık.

\section{Gereç ve Yöntem}

Çalışma, Gülhane Askeri Tıp Akademisi yerel etik kurul komitesinin 03 Temmuz 2013 tarih-1655 sayılı izni ile gerçekleştirilmiştir. Beytepe Asker Hastanesi'ne 01 Haziran 201131 Mayıs 2013 tarihleri arasında çeşitli nedenlerle başvuran ve HBs $\mathrm{Ag}$, Anti-HBs, Anti-HBc total, Anti-HCV tetkikleri istenen toplam 11758 hastanın kayıtları geriye dönük olarak değerlendirilmiş ve bunlardan 11728 hastanın HBsAg, 2378 hastanın Anti-HBs, 1256 hastanın Anti-HBc total ve 7615 hastanın Anti-HCV test sonuçları çalışmaya dahil edilmiştir.

Hepatit belirteçleri (HBsAg, anti-HBs, Anti-HBc Total ve Anti$\mathrm{HCV}$ ) ticari kemilüminesan enzim immünoassay tekniği (Architect i1000SR, Abbott, ABD) ile çalışılmıştır. Metodun belirteçlere ait performans verileri sırasıyla; HBsAg için, çalışma-içi tekrarlanabilirlik değerleri \%1,9-5,1, gün-içi tekrarlanabilirlik değerleri ise \%2-7,9 arasında olup, düşük pozitif panel için laboratuvar-içi kesinlik düzeyleri \%2,3-4,1 aralığındadır. Duyarııı̆̆ \%99,09, özgüllüğü \%99,91'dir. Anti-HBs için test-içi tekrarlanabilirlik değerleri \%1,9-6,5, testlerarası tekrarlanabilirlik değerleri \%3-8,6 ve total tekrarlanabilirlik değerleri \%7,4-13,1 aralığındadır. Özgüllüğü \%99,67 ve duyarlılı̆ı \%97,54'dir. Anti-HBc Total için test-içi kesinlik değerleri \%2,52-6,52 aralığındadır. Özgüllüğü \%99,71, duyarlıı̆̆ \%100'dür. Anti-HCV için test-içi kesinlik değerleri \%3,5-5,6, testler-arası kesinlik değerleri \%4,3-8,4 ve total kesinlik değerleri \%5,1-13,4 aralığındadır. Özgüllüğü \%99,60 ve duyarlılığı \%99,10'dur.

\section{Bulgular}

Hastaların genel dağılımı incelendiğinde HBsAg sonucuna ulaşılan 11728 hastanın \%94,26'sının erkek ve \%5,74'ünün kadın olduğu tespit edilirken genel HBsAg pozitifliğinin \%2,54 (298/11728) olduğu gözlenmiştir. Cinsiyetlere göre değerlendirildiğinde ise HBsAg pozitifliği oranının erkeklerde \%2,62 (290/11055), kadınlarda \%1,19 (8/673) olduğu tespit edilmiştir. Yaş gruplarına göre değerlendirildiğinde ise; en sık pozitiflik oranı 40-49 yaş grubunda saptanmış olup $(\% 3,46)$, erkeklerde $28 / 766(\% 3,65)$ ve kadınlarda ise 2/101 (\%1,98) oranlarında olduğu bulunmuștur (Tablo 1).

Anti-HBs sonuçları değerlendirildiğinde; 2030 erkek $(\% 85,36)$ ve 348 kadın $(\% 14,64)$ olmak üzere toplam 2378 hastanın sonuçları çalışmaya dahil edilmiştir. Hastaların \%43,9'unun (1044/2378) AntiHBs düzeyi bağışıklık için yeterli bulunurken (Anti-HBs >10 mlU/ $\mathrm{ml}$ ) erkeklerde bu oran \%42,22 (857/2030), kadınlarda ise \%53,74 (187/348) olarak tespit edilmiştir (Tablo 2).

Çalışma kapsamında 1062'si erkek (\%84,55), 194'ü kadın (\%15,45) toplam 1256 hastanın Anti-HBc total sonuçları değerlendirilmiştir. Erkeklerdeki Anti-HBc total pozitifliği \%24,86 (264/1062), kadınlardaki ise \%13,92 (27/194) ve genel pozitiflik oranı ise \%23,17 (291/1256) olarak tespit edilmiştir. Anti $\mathrm{HBc}$ total testi pozitif olan hastaların \%53,95'inde (157/291) HBsAg pozitifliği mevcut iken, \%37,46'sında (109/291) Anti-HBs pozitifliği tespit edilmiştir.

\begin{tabular}{|c|c|c|c|c|c|c|}
\hline \multirow{2}{*}{$\begin{array}{l}\text { Yaş Grupları } \\
\leq \mathbf{9} \text { yaş }\end{array}$} & \multicolumn{2}{|c|}{ Erkek n (\%) } & \multicolumn{2}{|c|}{ Kadın n (\%) } & \multicolumn{2}{|c|}{ Toplam n (\%) } \\
\hline & $0 / 14$ & 0 & $0 / 17$ & 0 & $0 / 31$ & 0 \\
\hline $10-19$ yaş & $0 / 59$ & 0 & $0 / 39$ & 0 & $0 / 98$ & 0 \\
\hline $20-29$ yaş & $240 / 8535$ & 2,81 & $2 / 245$ & 0,82 & $242 / 8780$ & 2,76 \\
\hline $30-39$ yaş & $19 / 1515$ & 1,25 & $3 / 184$ & 1,63 & $22 / 1699$ & 1,29 \\
\hline $40-49$ yaş & $28 / 766$ & 3,65 & $2 / 101$ & 1,98 & $30 / 867$ & 3,46 \\
\hline $50-59$ yaş & $3 / 132$ & 2,27 & $0 / 42$ & 0 & $3 / 174$ & 1,72 \\
\hline $60-69$ yaş & $0 / 22$ & 0 & $1 / 34$ & 2,94 & $1 / 56$ & 1,78 \\
\hline$\geq 70$ yaş & $0 / 12$ & 0 & $0 / 11$ & 0 & $0 / 23$ & 0 \\
\hline Toplam & $290 / 11055$ & 2,62 & $8 / 673$ & 1,19 & $298 / 11728$ & 2,54 \\
\hline
\end{tabular}




\begin{tabular}{|c|c|c|c|c|c|c|}
\hline \multirow{2}{*}{$\begin{array}{l}\text { Yaş Grupları } \\
\leq \mathbf{9} \text { yaş }\end{array}$} & \multicolumn{2}{|c|}{ Erkek n (\%) } & \multicolumn{2}{|c|}{ Kadın n (\%) } & \multicolumn{2}{|c|}{ Toplam n (\%) } \\
\hline & $5 / 6$ & 83,33 & $14 / 16$ & 87,5 & $19 / 22$ & 86,36 \\
\hline $10-19$ yaş & $13 / 19$ & 68,42 & $16 / 17$ & 94,12 & $29 / 36$ & 80,55 \\
\hline $20-29$ yaş & $687 / 1677$ & 40,96 & $39 / 83$ & 46,98 & $726 / 1760$ & 41,25 \\
\hline $30-39$ yaş & $60 / 148$ & 40,54 & $63 / 130$ & 48,46 & $123 / 278$ & 44,24 \\
\hline $40-49$ yaş & $67 / 136$ & 49,26 & $35 / 66$ & 53,03 & 102/202 & 50,49 \\
\hline $50-59$ yaş & $22 / 37$ & 59,46 & $14 / 25$ & 56 & $36 / 62$ & 58,06 \\
\hline $60-69$ yaş & $2 / 6$ & 33,33 & $6 / 9$ & 66,66 & $8 / 15$ & 53,33 \\
\hline$\geq 70$ yaş & $1 / 1$ & 100 & $0 / 2$ & 0 & $1 / 3$ & 33,33 \\
\hline Toplam & $857 / 2030$ & 42,22 & $187 / 348$ & 53,73 & $1044 / 2378$ & 43,9 \\
\hline
\end{tabular}

\begin{tabular}{|c|c|c|c|c|c|c|}
\hline \multirow{2}{*}{$\begin{array}{l}\text { Yaş Grupları } \\
\leq \mathbf{9} \text { yaş }\end{array}$} & \multicolumn{2}{|c|}{ Erkek n (\%) } & \multicolumn{2}{|c|}{ Kadın n (\%) } & \multicolumn{2}{|c|}{ Toplam n (\%) } \\
\hline & $0 / 8$ & 0 & $0 / 8$ & 0 & $0 / 16$ & 0 \\
\hline $10-19$ yaş & $0 / 49$ & 0 & $0 / 32$ & 0 & $0 / 81$ & 0 \\
\hline $20-29$ yaş & $34 / 6340$ & 0,54 & $0 / 232$ & 0 & $34 / 6572$ & 0,52 \\
\hline $30-39$ yaş & $4 / 316$ & 1,26 & $0 / 170$ & 0 & $4 / 486$ & 0,82 \\
\hline $40-49$ yaş & 2/190 & 1,05 & $0 / 87$ & 0 & $2 / 277$ & 0,72 \\
\hline $50-59$ yaş & $0 / 62$ & 0 & $0 / 41$ & 0 & $0 / 103$ & 0 \\
\hline $60-69$ yaş & $0 / 22$ & 0 & $1 / 32$ & 3,12 & $1 / 54$ & 1,85 \\
\hline$\geq 70$ yaş & $0 / 13$ & 0 & $1 / 13$ & 7,69 & $1 / 26$ & 3,85 \\
\hline Toplam & $40 / 7000$ & 0,57 & $2 / 615$ & 0,32 & $42 / 7615$ & 0,55 \\
\hline
\end{tabular}

Ayrıca, çalışmamızda 7000 erkek (\%91,92) ve 615 kadın (\%8,08) olmak üzere 7615 hastanın Anti-HCV sonucu değerlendirilmiştir. Genel Anti-HCV pozitifliği \%0,55 (42/7615) olarak belirlenirken cinsiyetlere göre değerlendirildiğinde Anti-HCV pozitifliğinin erkeklerde \%0,57 (40/7000), kadınlarda ise \%0,32 (2/615) olduğu tespit edilmiştir (Tablo 3).

\section{Tartıșma}

Kronik HBV taşıyıcılığı hastalığın toplumda yayılmasına önemli oranda katkıda bulunarak toplum sağlığını etkilemekle birlikte ortaya çıkardığı sonuçlarla ülke ekonomisini de çok yakından ilgilendirmektedir. Ülkemizin de içerisinde yer aldığı orta endemik bölgelerde HBsAg pozitifliğinin \%2-8, Anti-HBs pozitifliğinin ise \%20-60 arasında olduğu bildirilmektedir. Ülkemizden yapılan yayınların incelendiği bir meta-analizde 1985-1999 yıllarında HBsAg pozitifliği \%5,2 iken, 2000-2005 yıllarında \%2,97 olarak saptanmış ve anlamlı bir azalma olduğu bildirilmiştir (2). Çalışmamızda tüm yaş gruplarının dahil edildiği genel HBsAg pozitiflik oranı \%2,54 olarak bulunmuştur. Bununla birlikte hastanemizin hizmet verdiği popülasyonun daha çok 20-29 yaş arası erkek hastalar olduğu göz önüne alındığında bu gruptaki seropozitiflik oranı ise \%2,76 olarak saptanmıştır. Ülkemizde benzer yaş grubu erkek hastalar ile ilgili yapılan çalışmalar incelendiğinde bunların daha çok kan donörlerinde yapılan çalışmalar olduğu dikkat çekmekle birlikte HBsAg pozitiflik oranı \%2,53-6,2 aralığında bulunmuştur $(4,5)$. Son beş yılda yapılan çalışmalarda ise yine kan donörlerindeki $\mathrm{HBs} \mathrm{Ag}$ pozitifliği oranının \%0,37-2,83 arasında olduğu tespit edilmiştir
(6). Donörlerdeki prevalansın daha düşük olmasının nedeni olarak sorgulama formları ile ön elemeden geçmeleri gösterilmektedir. Bu çalışmalarda da görüldüğü üzere ülkemizde genç erişkin erkeklerdeki HBsAg pozitifliği, ülkemizin HBV endemisitesine uyumlu olarak saptanmakla birlikte bir düşme eğilimi dikkat çekmektedir. Bizim çalışmamızda da genel HBsAg pozitiflik oranının ülkemizdeki genel prevalans ile uyumlu olduğu tespit edilmiştir.

HBV enfeksiyonlarının önlenmesinde aşılama çok önemli bir konudur. DSÖ, 1992 yılında hepatit B aşısının da genişletilmiş bağışıklama programına (GBP, Expanded Programme on Immunization-EPI) alınmasını önermiş ve 1995 yılına kadar taşıyıcıığı \%8 ve üstünde olan ülkelerde, 1997 yılına kadar ise tüm ülkelerde ulusal aşı programına eklenmesini tavsiye etmiştir. Ülkemizde 1998 yılından bu yana tüm yenidoğanlara ücretsiz olarak hepatit B aşısı yapılmaktadır. Bu durum göz önünde bulundurulduğunda, çalışmalardan elde edilen sonuçların değerlendirilen yaş grubu ile değişkenlik göstermesi doğaldır. Örneğin Sivas ilinde, ilkokul birinci sınıf öğrencileri üzerinde yapılan bir çalışmada Anti-HBs pozitifliğinin \%73,9 oranında olduğu gözlenirken HBsAg pozitifliğinin \%0,16 gibi oldukça düşük bir oranda olduğu tespit edilmiştir (7). Bu rakamlar değerlendirildiğinde HBV enfeksiyonuyla mücadelede aşılamanın oldukça etkili olduğu ve bu konuda yapılan çalışmaların iyi sonuçlar verdiği söylenebilir. Bizim çalışmamızda ise Anti-HBs seropozitifliği \%43,9 oranında saptanmıştır. Bu oran orta endemik bölgeler için bildirilen \%20-60 Anti-HBs seropozitifliği ile uyumludur. Yine literatürlerle uyumlu olarak bizim çalışmamızda da en sık seropozitiflik oranı 20 yaş altı popülasyonda gözlenmiştir (8). 
Hepatit C virüsünün tanımlandığı 1980'li yıllarda gelişen posttransfüzyonel hepatitlerin \%90'ından sorumlu olduğu sonradan yapılan çalışmalarla belirlenmiştir. Ülkemizde 1996 yılında AntiHCV testinin donörlerde bakılmasının zorunlu hale getirilmesi ile transfüzyona bağlı HCV riskinde düşüş sağlanmıştır (6).

Dünyada HCV enfeksiyonu prevalansının yaklaşık \%2,2-3 arasında olduğu tahmin edilmektedir (9). En düşük prevalans Ingiltere ve Iskandinav ülkelerinden (\%1'in altında), en yüksek prevalans ise Mısır'dan (\%15-20) bildirilmiştir $(10,11)$. Ülkemizde ise bu oranın 2000'li yılların başında \%2,1-3,9 arasında değişkenlik gösterdiği belirtilirken, son yıllarda yapılan çalışmalarda Anti-HCV seropozitifliğinin $\% 0,85-1,5$ arasında olduğu gösterilmiştir $(8,12,13)$. Ayrıca, son 5 yılı kapsayan ve farklı kan merkezlerini baz alarak gerçekleştirilen çalışmalarda Anti-HCV pozitifliğinin \%0,35-0,4 arasında değiştiği gösterilmiştir $(14,15)$. Bizim çalışmamızda ise literatürlerle uyumlu olarak Anti-HCV seropozitiflik oranı \%0,55 olarak tespit edilmiştir.

Sonuç olarak, HBV ve HCV enfeksiyonları dünya ve ülkemiz için hala önemli bir sorun olmayı sürdürmektedir. Dolayısıyla bu hastalıkların önlenmesinde kronik taşıyıcıların belirlenmesi hala önemli bir noktadır. Ülkemiz HBV açısından halen orta endemisite (\%2-10) bölgesinde olmakla birlikte uygulanan ulusal aşılama programının neticesinde HBsAg seropozitifliğinin giderek azaldığı dikkat çekmektedir. Önümüzdeki yıllarda halkın hastalık hakkında daha fazla bilgi sahibi olması, etkin aşılama programlarının uygulanması, evlilik öncesinde veya farklı nedenlerle yapılan taramalar gibi önlemler neticesinde ülkemiz düşük endemisite $(<\% 2)$ bölgesindeki ülkeler arasına dahil olabilir. Ancak epidemiyolojik çalışmaların aksatılmadan devam ettirilerek seroprevalansların belirlenmesinin ve toplumu bilgilendirme çalışmalarının sürekli olarak yapılmasının uygun olacağı bildirilmektedir.

\section{Çıkar Çatışması: Bildirilmemiştir.}

\section{Kaynaklar}

1. Toy M, Önder FO, Wormann T, Bozdayı AM, Schalm SW, Borsboom GJ, van Rosmalen J, Richardus JH, Yurdaydın
C. Age- and region-specific hepatitis B prevalance in Turkey estimated using generalized linear mixed models: a systematic review. BMC Infectious Diseases 2011; 11:337.

2. Mıstık R. Türkiye'de viral hepatit epidemiyolojisi yayınlarının irdelenmesi. Ed. Tabak F, Balık I, Tekeli E. Viral Hepatit 2007. Istanbul: Viral Hepatitle Savaşım Derneği, 2007: 10.

3. Ökten A. Hepatit C-Giriş. Ed. Kılıçturgay K, Badur S. Viral Hepatit 2001. Istanbul: Viral Hepatitle Savaşım Derneği, 2001: 180.

4. Emiroğlu HH, Kesecik M, Oğuz S, Oztürk M, Nazlıgül Y, Altunay H. Şırnak'taki asker ve sivillerde asemptomatik HBV taşıyıcılığı prevalansı. Viral Hepatit Derg. 2000; 1: 18-20.

5. Mutlu B, Meriç M, Willke A. Kan donörlerinde Hepatit B ve C virüsü, insan immün yetmezlik virüsü ve sifiliz seroprevalansı. Mikrobiyol Bül. 2004; 38: 445-8.

6. Deveci Ö, Tekin A, Günbay SS, Kılıç D, Kaygusuz S, Ağalar C Özer TT. Kan bağışçılarında HBs Ag, anti-HCV, anti-HIV ve VDRL testi sonuçlarının değerlendirilmesi. J Clin Exp Invest. 2011; 2(4): 416-9.

7. Ayvaz A, Nur N, Engin A, Cetinkaya S. Sivas il merkezinde yaşayan ilkokul birinci sınıf öğrencisi çocuklarda hepatit $B$ ve hepatit C yaygınlığı. Türk Ped Arș. 2010; 45: 132-6.

8. Inci $A$, Okay $M$, Güven D. Artvin Devlet Hastanesine Başvuran Hastalarda HBs Ag, Anti-HBs, Anti-HCV ve Anti-HIV Seroprevalansı. Viral Hepatit Derg. 2013; 19(1): 41-4.

9. Barut HS, Günal Ö. Dünyada ve Ülkemizde Hepatit C Epidemiyolojisi. Klimik Dergisi. 2009; 22(2): 38-43.

10. Alter MJ. Epidemiology of hepatitis $\mathrm{C}$ virus infection. World $\mathrm{J}$ Gastroenterol. 2007; 13(17): 2436-41.

11. Frank C, Mohamed MK, Strickland GT, Lavanchy D, Arthur $R R$, Magder LS, et al. The role of parenteral antischistosomal therapy in the spread of hepatitis C virus in Egypt. Lancet. 2000; 355(9207): 887-91.

12. Asan A, Akbulut A, Saçar S, Turgut H. Tunceli Devlet Hastanesine Başvuran Kişilerde HBs Ag ve Anti-HCV seroprevalansının değerlendirilmesi. Viral Hepatit Derg. 2011; 17(2): 52-6.

13. Çetinkol Y. Kars Devlet Hastanesine Başvuran Hastalarda HBsAg, anti-HCV ve anti-HIV seroprevalansı. Viral Hepatit Derg. 2012; 18(2): 76-80.

14. Altındiş M, Aslan S, Kalaycı R. Kan vericilerinde HBsAg, antiHCV, anti-HIV ve Sifiliz seroprevalansı. Sakarya Med J. 2011; 1(1): 22-6

15. Ulutürk R. Kan donörlerinde yapılan rutin tarama testlerinin 11 yıllık değerlendirilmesi. Türk Mikrobiyol Cem Derg. 2010; 40(1): 41-7. 